\title{
Our Heritage Is Already Broken: Meditations on a Regenerative Conservation for Cultural and Natural Heritage
}

\author{
Michael Kimball ${ }^{2}$ \\ Department of Anthropology \\ College of Humanities and Social Sciences \\ University of Northern Colorado, United States
}

They must find a way to love the sublime presence of waste and garbage in our world. Love ... is not an abstract idealization but it is an acceptance of the world with all its failures and flaws - a way of seeing perfection in imperfection itself - a parallax view of something where flaw and virtue are one and the same. (Russell, 2012, p. 260)

Consider the following story:

In 2001, several months before the September 11 attacks on the World Trade Center, the Taliban regime ordered the destruction of all "shrines of infidels" (Manhart, 2009, p. 38), including two colossal 6th-7th century CE statues of the Buddha carved into cliff faces in central Afghanistan's Bamiyan Valley during this region's heyday as a Silk Road hub. The demolition of the Bamiyan Buddhas (Figure 1), executed with mortar fire and dynamite and filmed by the Taliban, incited international shock and outrage. How could this destruction have been allowed to happen to such an invaluable historical treasure? These statues had existed for more than 1,400 years and now, in the space of a few weeks, were all but completely erased. In 2003, the United Nations Educational, Scientific and Cultural Organization (UNESCO) responded by designating the cultural landscape and archaeological remains of the Bamiyan Valley as a World Heritage site and adding them to the World Heritage in Danger List, thereby authorizing their "Outstanding Universal Value" and need for protection (UNESCO, n.d.). Since then, experts have journeyed to Bamiyan to conduct archaeological excavations and shore up

\footnotetext{
$1 \quad$ I presented a schematic of this paper, entitled "Which Heritage, for Whom?" at the Society for Human Ecology XX International Conference, Bar Harbor, Maine, October 2014. I wish to thank members of the audience and two anonymous reviewers of this paper's original manuscript whose comments led to clarifications on and improvements of the ideas and arguments in this essay.

2 Author contact: michael.kimball@unco.edu.
} 
the niches in which the Buddha statues once stood. Thanks to UNESCO and the efforts of heritage professionals, what remains of Bamiyan's cultural heritage will be protected, interpreted and preserved for future generations.

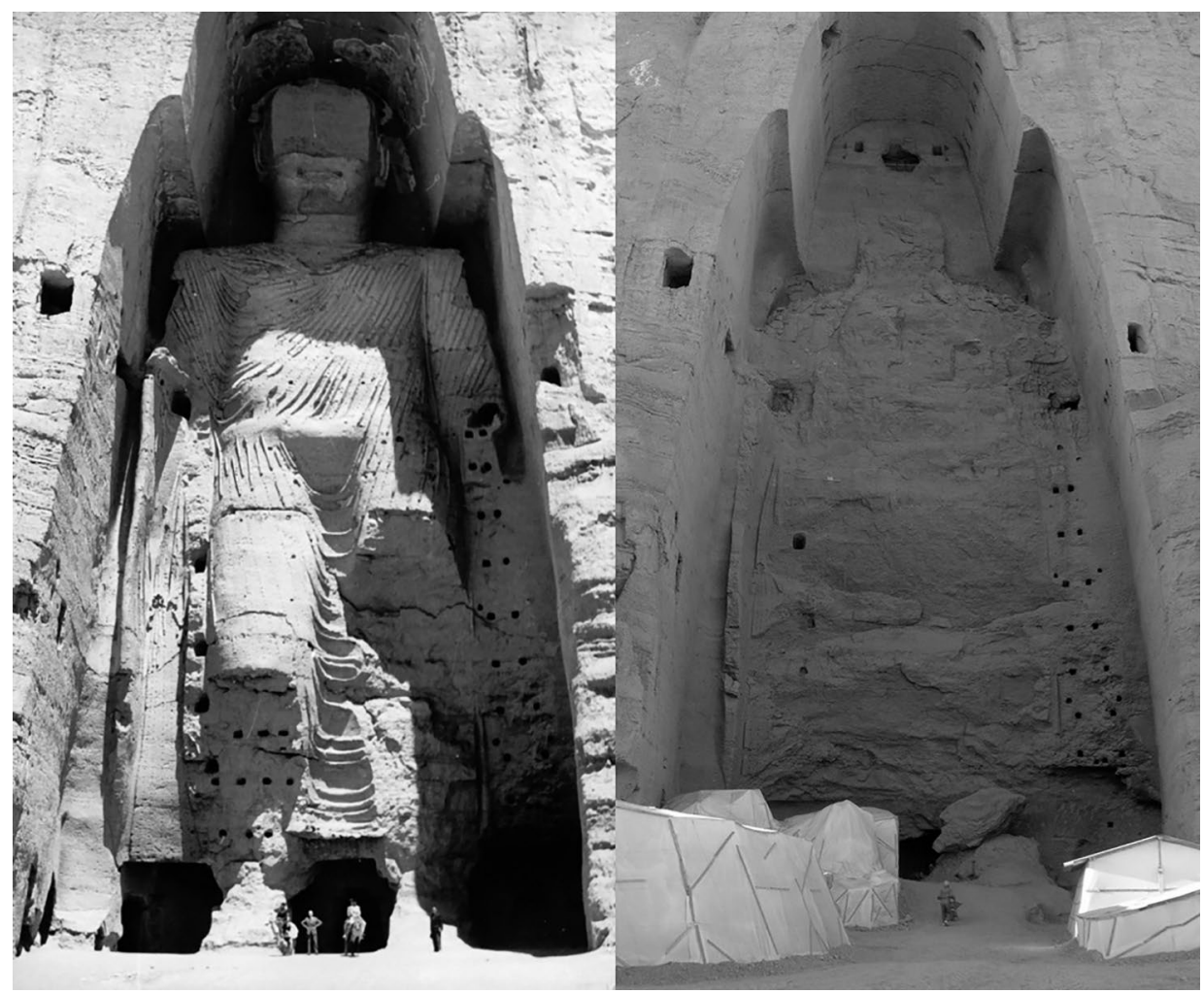

Figure 1. One of the Bamiyan Buddhas before and after destruction by the Taliban in 2001

Source: Wikimedia Commons, commons.wikimedia.org/wiki/File:Taller_Buddha_of_Bamiyan_before_ and_after_destruction.jpg. This image is licensed under the Creative Commons Attribution-Share Alike 3.0 Unported license.

This story, also told by other heritage scholars (e.g., Blänsdorf and Petzet, 2009; Holtorf, 2006; Jokilehto, 2006; Karlström, 2009; Peleggi, 2012) in different ways and for their own rhetorical reasons, seems to capture some of the essence of heritage - its fragility, our fear and sense of its loss, and our powerful drive to conserve it. Perhaps it is also a heroic tale, at least from a European/Americancentric world view, in which the forces of good do battle with the destructive (evil) forces of violence, ignorance, time, and entropy to save something of universal value. For some of us, this reading of the story is the only one that can or should be made. For others, however, there are different renditions that need to be heard, ones that are based on different world views and lived experience. For example, how would the Hazara - an ethnic group of Shia Muslims whose 
heritage includes deep roots in the Bamiyan Valley - tell this story? Who has listened deeply to their own stories and experience? How might the Hazara understand and care for their Bamiyan heritage?

This essay is about the interdependence of story and action with respect to cultural and natural heritage. It is also about the inexorability of change and its relationship to heritage conservation. In the following paragraphs, I share several stories and excerpts, some heroic, others less so (I leave it to the reader to decide which is which), to make the case that the traditional, Western perspective on heritage does not hold up well under scrutiny - there is now an emerging paradigm for heritage conservation, one that both realizes its "empty" nature and guides us in developing a conservation approach that aligns with this recognition.

To accomplish this, I have divided this essay into several parts. First, I define and critique the Western heritage conservation paradigm, which I call "postcard heritage," by exploring an archaeological example from Nepal's Mustang Valley and the theoretical example of the "postcard Indian." Second, I critically examine four axioms of postcard heritage via insights arising from an alternative heritage paradigm, one I term "empty heritage," inspired by Buddhist teachings and practice. Third, I cross an arbitrary boundary between cultural and natural heritage by briefly exploring the controversial and instructive case of the "postcard red wolf" and its alternative, the "empty red wolf." I conclude these meditations on a theme by contemplating the implications of an empty approach to cultural and natural heritage conservation - one that, to paraphrase the Thai Forest Tradition Buddhist monk, Ajahn Chah (2007), understands heritage to be "already broken" and concentrates on the transformative merit in a "regenerative conservation" of living, as opposed to fixed and essentialized, heritage.

\section{Postcard heritage}

The roots of my notion of postcard heritage extend into urban heritage conservation, specifically the ideas of urban designer, Rahul Mehrotra (2004). ${ }^{3}$ In his critical examination of the concept of cultural significance as it pertains to Mumbai's historic fort area, Mehrotra quotes a passage from Italo Calvino's novel, Invisible Cities (1974, p. 30), in which a city named Maurilia is described by the fictional character, Marco Polo:

3 My inquiries into Mehrotra's work began when I found a reference to it in Ioannis Poulios's thoughtprovoking book, The Past in the Present: A Living Heritage Approach-Meteora, Greece (2014, p. 127). 
In Maurilia, the traveler is invited to visit the city and, at the same time, to examine some old postcards that show it as it used to be ... If the traveler does not wish to disappoint the inhabitants, he must praise the postcard city and prefer it to the present one ...

Mehrotra (2004, p. 26) compares this "postcard city" theme to the attitudes of many conservation activists in Mumbai:

Unfortunately, most conservation debates discuss change in terms of the loss of something, as opposed to new possibilities, mostly because people ... will easily react to any sort of new condition as worse than some "magic moment" in the past ... the issue is how to simultaneously identify new typologies and work with them rather than dwell in the "postcard city," a city that only flights of nostalgia momentarily recreates.

Thus, postcard heritage conjures up an inaccessible past comprising lost "magic moments" - static snapshots of imagined places, landscapes, and peoples that we prefer over those existing in the present, which are always more complicated, if not contaminated, by their own histories and agency.

Consider the following story, inspired by one I heard from heritage scholar Neel Kamal Chapagain (2013a) in his presentation at the 7th World Archaeological Congress in Jordan:

In 2009 the National Geographic Society released a documentary, evocatively entitled Secrets of Shangri-La. This particular Shangri-La consists of more than 10,000 human-built caves in the cliff faces of Mustang Valley in northern Nepal. In the documentary's preview, ${ }^{4}$ we accompany scholars and explorers as they rappel from the top of a cliff down to the alcove entrances, kicking off large chunks of the cliff face as they do so and shouting "rock!" to their colleagues down below. They express disbelief and wonder at their discovery of stunning 15th century murals, manuscripts and burials representing the valley's indigenous Bön and Buddhist heritage. Their next step is to figure out a way to rescue some of these unprotected masterpieces.

I conducted a simple content analysis of the documentary's preview and identified several key words and phrases used in the video's narrative, namely: priceless, hidden, masterpiece, discovery, unprotected, rescue, finds, mysterious, beckon, lost world, first time, secrets. This kind of language, of course, can be attributed in part to savvy marketing for Western viewers, but such a suspicion only underscores the fact that there's something deeper going on here. Words and phrases such as these are part of a powerful Western "authorized heritage

4 I recommend that readers watch the preview, available at www.youtube.com/watch?v=IRLyJbt6wvs. 
discourse" (Smith, 2006, p. 29) that dictates the meaning, value, and purpose of cultural heritage. Chapagain (in press) summarizes and critiques this Mustang Valley heritage narrative as follows:

To me there appeared to be a fundamental misunderstanding of the notion of heritage in such contexts. Many of the Buddhist (and for that matter, even pre-Buddhist) sites contain objects or texts that are not supposed to be taken out of their respective places ... In attempting to "discover" and claim our "authority" over this heritage through documentation and preservation efforts, we may be crossing cultural boundaries of respect for the underlying concepts behind the materiality and spirituality contained therein.

Indeed, these artifacts and features were not calling out for recognition and protection by Western scholars; they had been stewarded by their environmental context and the custodial oversight of local people and had endured as an integral part of landscape and culture for centuries. It is also interesting to point out that the caves, equally sacred to the local community, were treated by the scholars and explorers as a disposable backdrop, likely because they were perceived by them as merely value-neutral containers for highly valued cultural heritage artifacts.

Another example of this paradigm can be found in what I refer to as the theoretical "postcard Indian" (Figure 2) who regards us from the safe (that is, for non-Native Americans) confines of a nostalgic, two-dimensional tableau. But as archaeologist Matthew Liebmann (2008, pp. 76-77) writes,

Popular portrayals of ... fictionalized Native Americans in the mass media have lent credence to the romantic fantasy that these so-called "real Indians" still exist somewhere, unaffected by colonization. These imaginary Indians ultimately prove more desirable to mainstream society than modern Native Americans, who suffer by comparison and are often ignored or marginalized when they attempt to explain their differences through complex histories of dynamic adaptation [emphasis added]. 


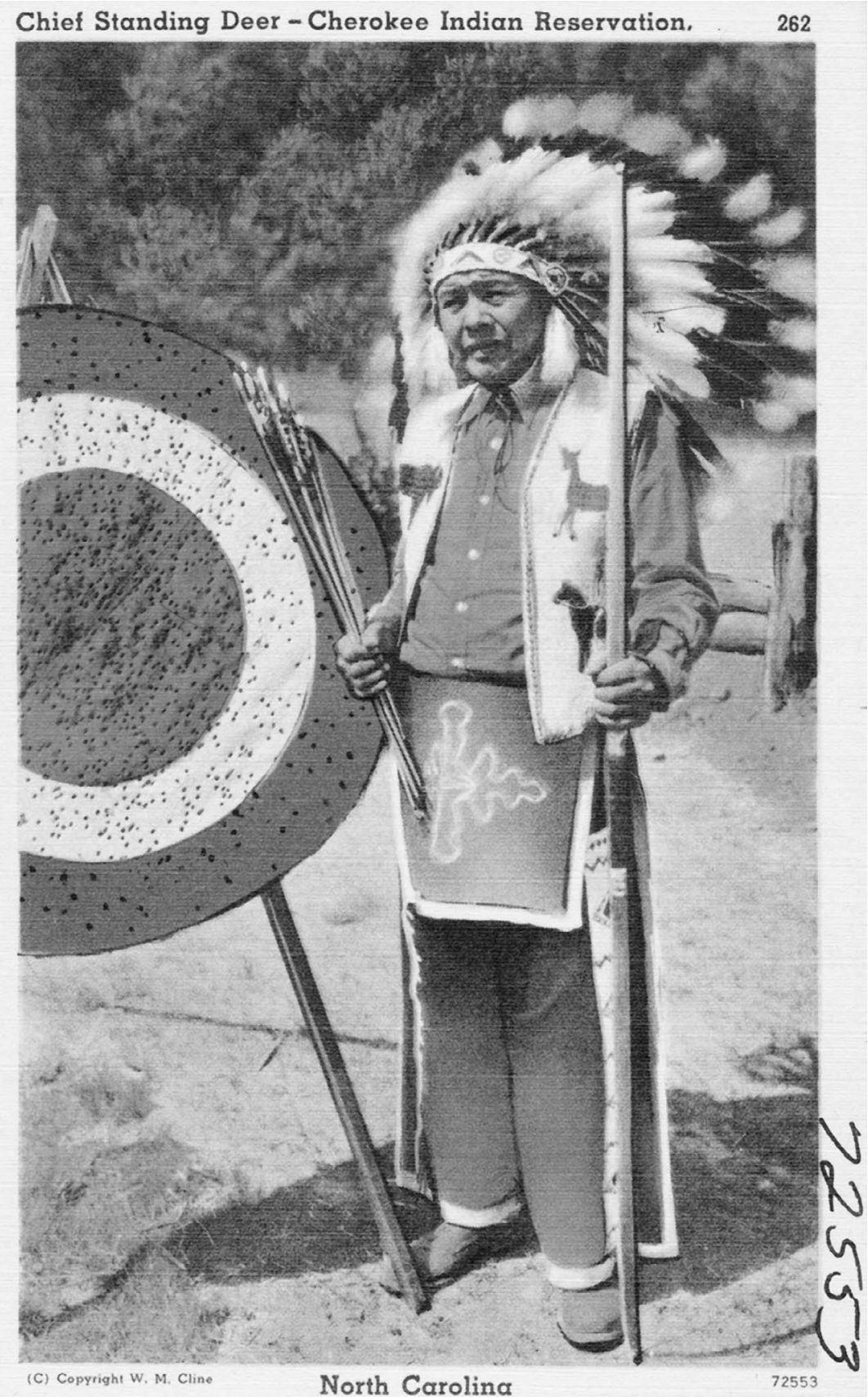

Figure 2. Chief Standing Deer, Cherokee Indian Reservation, North Carolina. This vintage postcard exemplifies the fantasized Indian who replaces "modern Native Americans, who suffer by comparison" (Liebmann, 2008, pp. 76-77).

Source: Wikimedia Commons, commons.wikimedia.org/wiki/File:Chief_Standing_Deer_-_Cherokee_ Indian_Reservation,_North_Carolina_(5756035888).jpg. This image is licensed under the Creative Commons Attribution 2.0 Generic license. 
The postcard Indian is the fixed, fantasized and essentialized Native American, whose real existence is replaced by an imagined one, which, as it is colonized, sanitized, and commodified, becomes increasingly alienated from its referent. This relegation - indeed, expulsion - of peoples and their histories from their living contexts to the literal and figurative cardboard context of postcards brings to mind French sociologist Jean Baudrillard's (1994, p. 8) notion of "referential simulacra" - replicas that we conjure up and sever from their referents, a "real without origin or reality" (ibid., p. 1). For example, Baudrillard examines the case of the Tasaday people of the Philippines, a putatively uncontacted "stone age" culture "discovered" in the 1960s. In the early 1970s, the Philippine government relocated the Tasaday to a reserve and effectively sealed them away from anthropological investigation, allegedly to protect them from harm. ${ }^{5}$ Baudrillard (1994, p. 8) writes with respect to the role of science-in this case, ethnology - in creating simulacra:

The Indian ... in the glass coffin of the virgin forest, again becomes the model of simulation of all the possible Indians from before ethnology. This model thus grants itself the luxury to incarnate itself beyond itself in the "brute" reality of these Indians it has entirely reinvented-Savages who are indebted to ethnology for still being Savages ... Of course, these savages are posthumous: frozen, cryogenized, sterilized to death, they have become referential simulacra, and science itself has become pure simulation.

This "sterilization," the product of a collusion, Baudrillard argues, between science and mass media, is not a harmless act-it distracts and prevents us from recognizing the actual heritage, comprising Liebmann's (2008) complex histories of dynamic adaptation, which is manifest in the minds, hearts, bodies and culture of living Native Americans.

By imagining the postcard Indian into being, we assign his or her people a kind of contingent merit, which rises or falls in accordance with the value of a heritage authorized by managers, scholars, stakeholders, other delineated groups (e.g., Americans, Europeans, global citizens, tourists), or a generic humanitythat is, what heritage scholar Laurajane Smith (2006, p. 29) refers to as our "nebulous future generations." Heritage scholar Ioannis Poulios (2010) points to this idea in his critique of a values-based approach to heritage conservation, one in which authorized stakeholders of one kind or another disproportionately influence the interpretation and management of heritage places. Likewise, Sullivan (2004, p. 53) cites the example of Australia's Kakadu National Park, in which contingent merit is assigned to a postcard Aboriginal community:

5 This is a controversial and convoluted case that features a long-term debate over whether the Tasaday represented a "real" or fabricated cultural group and whether, as linguist Lawrence Reid claims (1993, p. 2), the "hoax proponents were themselves the hoax makers." Although Baudrillard does not discuss this debate, it fits neatly into his thesis on the nature of referential simulacra. 
Members of a World Heritage delegation who visited the Kakadu National Park on a mission to assess whether it was endangered by uranium mining found in their report that the one small modern settlement in an area the size of Belgium, which provided health, modern housing, education and transport facilities for the indigenous owners of the Park, as well as tourism revenue and mining royalties, was undesirable and a threat to the area's World Heritage values because it was seen as a blot on the pristine landscape and also as inimical to the traditional lifestyle of the owners.

In sum, postcard heritage possesses a set of core perspectives, which I summarize here via four axioms: (1) heritage contains essential qualities; (2) many of these qualities have or should have fixed manifestations (objects, places, traditional lifeways, etc.) that, when possible, should be rendered permanent against the passage of time; (3) these manifestations are independent of and discontinuous with contemporary cultural contexts; and (4) they possess contingent merit that must be assessed and authorized by experts and stakeholders.

\section{Empty heritage}

I begin this section with an author's disclosure and disclaimer. Among other things and in different contexts, I identify as a Euro-American heterosexual male, an archaeologist trained within a Western positivist tradition, a human ecologist and engaged anthropologist, and a practitioner of Buddhist teachings. I am not a scholar of Buddhism. What follows includes my own distillation, synthesis, and application of others' scholarship of Buddhist philosophy, culture, and heritage. Buddhism is not monolithic; it comprises a rich diversity of interpretations and practices within and across a vast array of Asian cultures and societies and broad traditions (Theravadan, Mahayana, Vajrayana). ${ }^{6}$ Further, Buddhism's much more recent introduction into relatively affluent Western societies has spawned a new wave of interpretations and practices befitting their own respective and varying orientations toward scientific inquiry, secularism, democracy, individualism, psychotherapy ("self help"), and so forth. This latter phenomenon and my own background influence my analyses and flavor my conclusions in ways that likely both help and hinder them.

Moreover, any project of this kind necessarily privileges generalization over particularization, which means that counterpoints to my claims about "a Buddhist perspective" on cultural heritage can (and should) undoubtedly be found in the particulars of philosophy, culture, and socioeconomics/politics

6 The Theravadan Buddhist Tradition is associated with South Asian and Southeast Asian cultures; the Mahayana Tradition is rooted in Tibetan, Japanese, and Chinese cultural heritage; the Vajrayana Tradition is found in Tibetan Buddhist culture. 
at certain spatio-temporal intersections within the so-called Buddhist world. Nevertheless, I believe my generalizations are useful in drawing attention to and articulating differences between a dominant heritage world view and a muchneeded alternative.

Although the postcard heritage paradigm exerts a hegemonic force on our conception and perception of heritage, it is possible to discern an opposing paradigm that is inseparable, as it were, from the sacred caves of Mustang Valley and Native Americans' complex histories of dynamic adaptation. In this paradigm, heritage lives in the minds, hearts, and practice of what my placebuilding colleagues and I call heritage "placekeepers" (Kimball et al., 2013) and what Poulios (2010, p. 176) calls the "core community," that is, those who consider a heritage place to be "an integral part of [their] contemporary life" (Poulios, 2014, p. 115). This paradigm recognizes that, rather than a fixed, fantasized, and essentialized product, heritage is actually a process, through which, as Smith (2006, p. 75) puts it, we "express, facilitate and construct a sense of identity, self and belonging." In deference to Buddhism, whose world view is consistent with this perspective, I refer to this paradigm as "empty heritage." 7

Empty heritage offers insights into each of the postcard heritage paradigm's four axioms: (1) heritage is, upon closer inspection, empty of any essential qualities; (2) the qualities we conceive and perceive are, instead, impermanent and inevitably change with the passage of time, despite our best efforts to freeze them in place; (3) heritage arises, changes, and passes away dependent on its causes and conditions - it is therefore interdependent and continuous in its relation to the past, present, and future; thus, (4) the merit of heritage can be transformative when its stewards aren't attached to static conceptions and rigid expectations. In the remainder of this section I expand upon these insights.

\section{Essentialism versus emptiness}

Below is an English translation of part of a Tibetan Buddhist version of the Prajnaparamita (or Heart) Sutra, in which the Buddha instructs his disciples on the inherent emptiness of all phenomena (FPMT, 2008):

all phenomena are emptiness; without characteristic; unproduced, unceased; stainless, not without stain; not deficient, not fulfilled ... therefore, in emptiness there is no form, no feeling, no discrimination, no compositional factors, no consciousness ... There is no ignorance, no extinction of ignorance,

7 I must distinguish my use of the term "empty heritage" from that appearing elsewhere. In the literature on heritage scholarship it is not uncommon to find the term "empty heritage" equated with the notion of "lost heritage," that is, an ethnic group's cultural or religious heritage that is forgotten, marginalized, or erased. 
and so on up to and including no aging and death and no extinction of aging and death. Similarly, there is no suffering, origination, cessation, and path; there is no exalted wisdom, no attainment, and also no non-attainment.

Where the postcard heritage paradigm is fundamentally essentialist, the empty heritage paradigm is rooted in this Buddhist realization of emptiness. As Khisty (2006, p. 302) writes of the Heart Sutra:

This text says that when one considers a particular object to be empty, it means it is empty of a separate, independent existence, because everything in this world has to inter-be with everything else, including the mind. It is empty of a separate self; but empty of a separate self means it is full of everything.

This perspective challenges an implicit assumption of postcard heritagethat heritage actually possesses authentic qualities, those that are intrinsically, objectively, and demonstrably genuine and which can (and must) be discovered, rescued, and preserved. A Buddhist investigation would ask, if authentic qualities exist, where can they be found? Are they in the materialthe structure, the substance, the DNA of an object? Alternatively, can these qualities be found in the mind of the heritage maker or heritage observer? Is there a substance in/to memory, experience, insight that can be apprehended as heritage? For example, where is the heritage in Mustang Valley? Can it be extracted from the manuscripts, the ink, the pigments? Is it in the skeletons of the people who wrote or illuminated the texts? Is it in their minds? Is it in the mind of placekeepers, the explorer, the scholar, the viewer of the Shangri- $\mathrm{La}$ documentary?

Consider the following paradox related by heritage scholar Jukka Jokilehto (2006, pp. 2-3):

A well-known case is the debate about the ship of Theseus, as told by Plutarch ... The ship was kept by the Athenians as a memorial for a long time. Due to gradual replacement of rotten planks, the ship retained its original form but its material was entirely renewed. The question was then raised: was it still the ship of Theseus?

The same question might be asked about restoration of art works, archaeological sites, and perhaps ecosystems. But this is only a conundrum for the postcard heritage paradigm. From an empty heritage perspective, the answer is to use a well-known Zen retort: $m u{ }^{8}$ That is to say, not yes and not no. In the words of the Prajnaparamita Sutra, there is no attainment and also no non-attainment. This is because the ship's authenticity, its "shipness," is a dynamic, interdependent

8 From a Western perspective, Jokilehto's question demands a resolution to the conundrum. From a Zen perspective, it may be read as a koan, the deep contemplation of which might allow one to short-circuit one's habitual conceptions and perceptions of heritage. 
conception, not a fixed and essential quality residing somewhere within the phenomenon itself. Jokilehto $(2006$, p. 3) goes on to wonder, "one could imagine that the materials that were removed would have been reassembled elsewhere in another ship. What would then be the significance of this other ship?" $M u$, once again.

\section{Fixity/permanence versus change/impermanence}

A correlate of the principle of emptiness - and one continuously performed through interactions between many Buddhist placekeepers and their heritageis that all phenomena are impermanent and always changing. This insight is manifested in the heritage that embodies and enacts cultural history. For example, there is Tibet's traditional butter-sculpture festival, which, prior to the Chinese invasion, ${ }^{9}$ was held annually in the monastery of Kumbum in eastern Tibet. This festival was the result of many months of work by monks who sculpted hardened butter into statues of abbots, teachers, bodhisattvas, and other figures, which were then publicly displayed on one day and destroyed before the dawn of the next. As Tibetan Buddhism scholar John Powers (1995, p. 196) writes, "this provided the audience with a graphic reminder that all mundane human activities pass away, leaving nothing behind."

A perhaps more familiar example for some might be the Tibetan sand mandala ritual (Figure 3) in which monks spend weeks painstakingly constructing out of colored sand an elaborate and finely crafted mandala - a highly stylized model of a sacred realm, which "represents both the nature of reality and the order of an enlightened mind" (Powers, 1995, p. 227). When the mandala is complete, it is swept up into piles, which are then removed and ceremoniously dumped into a nearby body of water. Some years ago, I visited the North Carolina Museum of Art while a group of visiting Tibetan monks was creating a sand mandala. I observed other visitors like myself manically snapping photos of the scene and couldn't help reflecting on the "moods and motivations" (to paraphrase Geertz, 1973) ${ }^{10}$ behind taking the pictures and the reality of their impermanence as either prints or pixels.

\footnotetext{
9 In 1950, during Mao Zedong's Cultural Revolution, the Chinese army invaded Tibet, destroying and looting monasteries, temples, and schools; killing and imprisoning thousands of people; and partitioning Tibet into Chinese provinces (Powers, 1995). The ebb and flow of China's influence in and on Tibet, as well as the cultural heritage of China and Tibet, which both suffered great losses during the Cultural Revolution, are themselves lessons in impermanence and interdependence.

10 Clifford Geertz used the term "moods and motivations" in his formulation of an anthropological definition of religion. According to Geertz (1973, p. 97), "motivations are 'made meaningful' with reference to the ends toward which they are conceived to conduce, whereas moods are 'made meaningful' with reference to the conditions from which they are conceived to spring."
} 


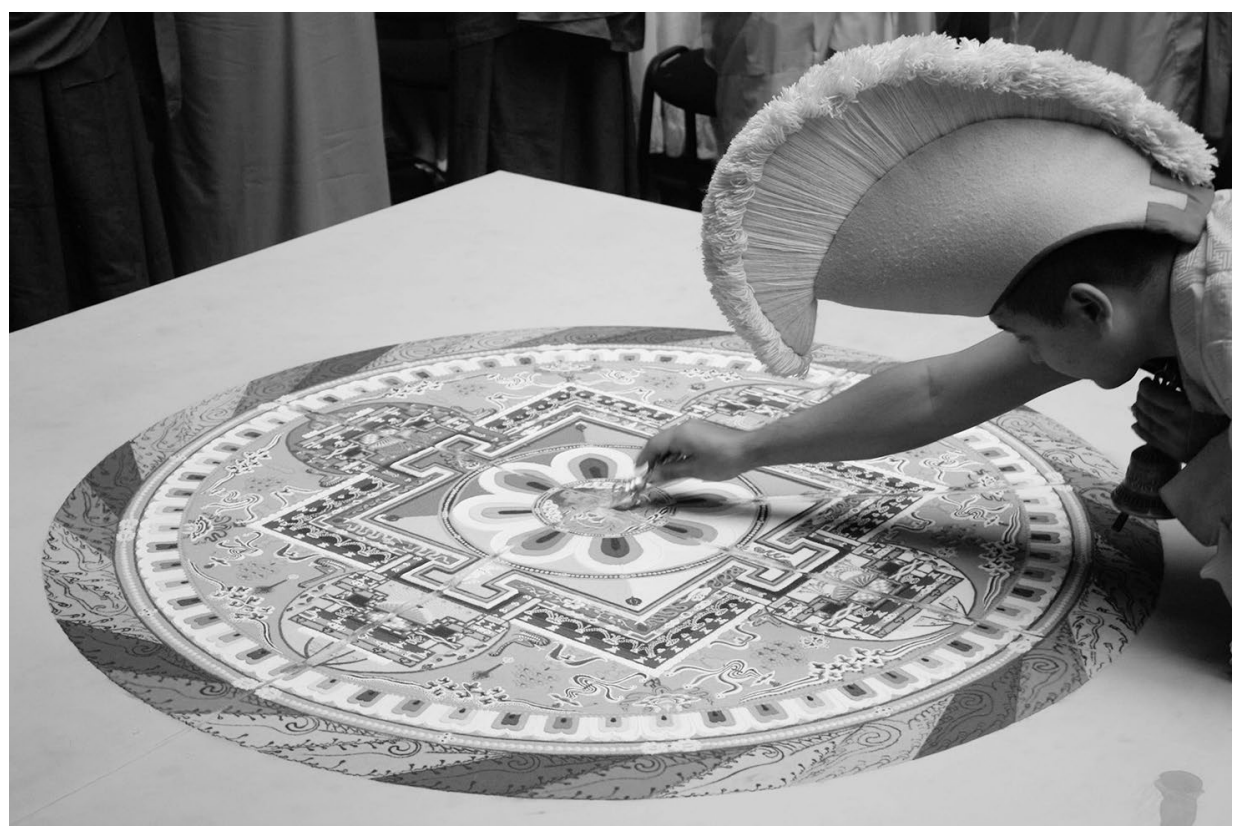

Figure 3. Tibetan Buddhist Green Tara sand mandala creation, Moscow

Source: Wikimedia Commons, commons.wikimedia.org/wiki/File:Mandala_zel-tary.jpg. This image is made available under the Creative Commons CC0 1.0 Universal Public Domain Dedication.

These examples not only show how Buddhist philosophy is manifested and taught through intangible (e.g., rituals) and tangible (butter and sand) cultural heritage, they also present heritage as synecdoche - a compression in time and space of a grand, inexorable, and cyclical process of birth, death, and decay for living beings, inanimate objects, places, and mental and social constructs alike.

\section{Independence/discontinuity versus interdependence/ continuity}

The postcard heritage paradigm views heritage as a discrete set of objects, places, and practices that, essentially, belong to the past and are discontinuous with the present (Poulios, 2010). As such, these objects, places, and practices can be delineated and abstracted from their cultural and environmental contexts and preserved in isolation as cultures (e.g., the Tasaday), skeletal remains, sites, artifacts, and so forth. The Shangri-La manuscripts, for example, are seen by Western scholars as possessing an existence independent of their contexts because they are apprehended as separate and separable-from the sacred caves, from their placekeepers - objects possessing their own inherent and fixed qualities. Thus, from this perspective it is possible, indeed justified 
and necessary, to collect and remove them from the caves and attempt to freeze them in their current state or restore them to a semblance befitting a previous and preferred condition and snapshot of time.

Through the lens of empty heritage, however, this construct dissolves. Fundamental to this kind of understanding of phenomena is the recognition of dependent arising (from the Sanskrit, pratityasamutpada), which holds that everything arises, persists, and passes away because its temporary existence depends on whatever lineages of phenomena brought it into being, whatever phenomena hold it in place and memory for a time, and whatever phenomena will inevitably cause its undoing.

Heritage epitomizes and embodies pratityasamutpada. This can be illustrated by an example from Bhutan's Tibetan Buddhist folklore - the widely known, taught, and revered folktale Four Harmonious Friends. Artwork (e.g., Figure 4) depicting this story can be found on stupas (sacred monuments), thangkas (sacred paintings), trucks, T-shirts, and the exterior and interior walls of buildings. The story more or less goes like this:

There was once a tree in a forest, laden with juicy and nutritious fruit. One day an elephant wandered past and, seeing the tree, announced that it belonged to him because he was the first to discover it. Upon hearing this, a monkey called down to the elephant from among the tree's branches, saying that, on the contrary, the tree belonged to him because he, the monkey, had been eating the tree's fruit well before the elephant came along. Then a rabbit hopped into the clearing and disagreed with them both, declaring that it was his tree because he had nibbled its leaves when it was but a sapling. Finally, a partridge appeared and informed the other animals that, in fact, the tree belonged to none of them because it was he who had dropped the very seed from which the tree had originally sprouted ...

Cultural researcher Steve Evans (2009, p. 8) offers the following epilogue for Four Harmonious Friends:

The four animals worked together and with their combined strength, each one benefited and no one went hungry. Other animals in the forest often saw them together, with the partridge on top of the rabbit, who was held up by the monkey, who rode on top of the elephant ... The four animals are looked upon as an example of peace, harmony, cooperation, interdependence and friendship. 


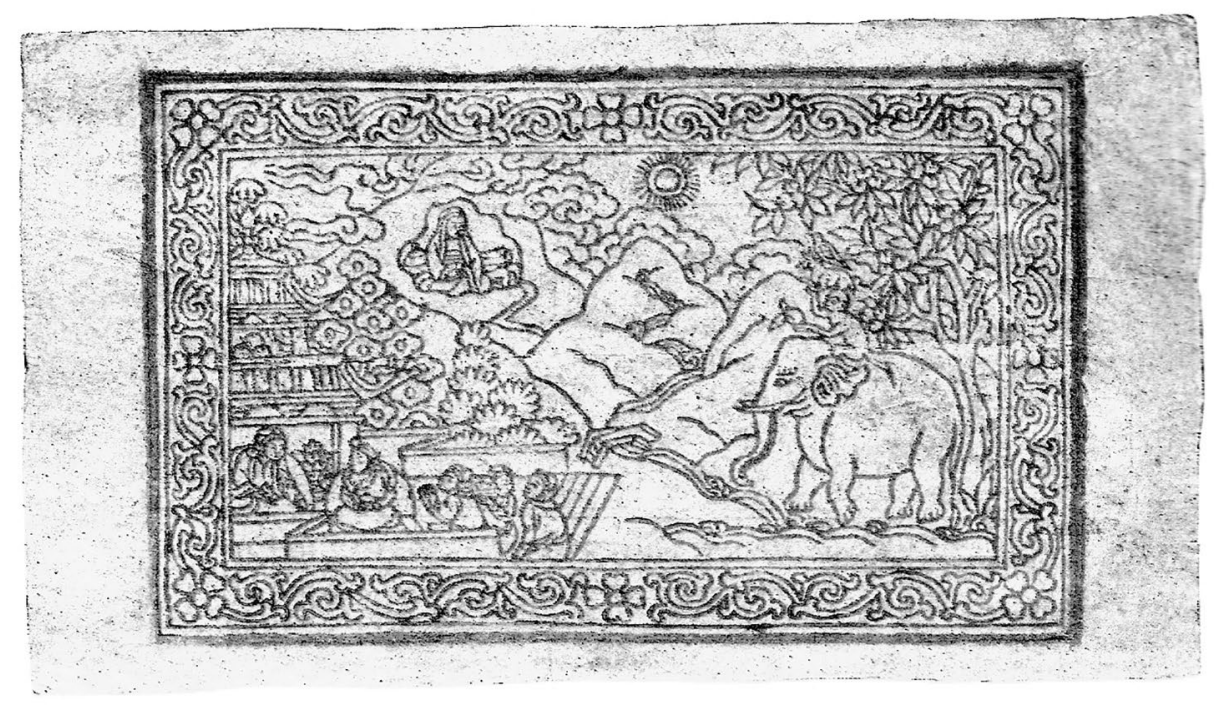

Figure 4. 25 Tam Tibetan bank note, circa 1913. Depiction of the "Four Harmonious Friends" (partridge on top of rabbit on top of monkey riding elephant) can be found on the right side of the image.

Source: Wikimedia Commons, commons.wikimedia.org/wiki/File:25_tam_back.jpg. This image is licensed under the Creative Commons Attribution-Share Alike 3.0 Unported license.

This folktale arises from a large body of ancient Buddhist allegories known as Jataka Tales (see Francis and Thomas, 1916), many of which are believed to reference the Buddha's previous non-human animal incarnations. However, it is not the only form in which this story appears. For example, while in Bhutan, Michael Noonan (n.d.), the founder of the Canisius Ambassadors for Conservation program, discussed Four Harmonious Friends with Tibetan Buddhist Lama Gembo Dorji and got an entirely different picture:

Noonan: When we see pictures of the four friends they are standing on each other.

Lama Dorji: So, that is the artistic version-also, to emphasize that the bird is the wisest, the eldest, sitting on the highest place over the other friends.

Noonan: It looks like they are using each other to reach the fruit. Is that not in the Sutra?

Lama Dorji: No. Nothing to do with that.

Noonan: So, it is not like they are cooperating to get this fruit. That's not the story that is in the Sutra?

Lama Dorji: No. That is not the story. In the Sutra, it is not mentioned. In the Sutra, only their life - how the Buddha has acquired all these merits, even when he was born as an animal ... [emphasis added] 
Noonan: Do some people tell the story of the four friends cooperating to get the fruit? Do some people change the story?

Lama Dorji: People can. They see the art in the painting and then they tell it that way. In other words, maybe to explain something differently. It is not that they are lying. It is just that we are using this as a kind of example, a kind of metaphor, to explain something ...

Thus, Lama Dorji's interpretation of Four Harmonious Friends seems to contradict Bhutan's ubiquitous lay interpretation. Both stories probably arise from what appears in the Vinaya-Pitaka, Buddhism's book of monastic rules and regulations, drawn from an oral tradition compiled, winnowed, and transcribed onto palm leaves arguably around 2,000 years ago. The Vinaya-Pitaka story, entitled "Allowance for the First Seat, etc.,"11 translated by I. B. Horner (2014, pp. 2210-2211) and originally published by the Pali Text Society in 1942, relates the following tale purportedly told by the Buddha himself to his monks:

Formerly, monks, there used to be a large banyan on a slope of the Himalayas. Three friends lived near it: a partridge, a monkey and a bull-elephant ... it occurred to these friends: "Now let us find out which of us is the eldest by birth. We should respect, revere, reverence, honour him, and we should abide by his advice." Then, monks, the partridge and the monkey asked the bull-elephant: "You, friend, what long-ago thing do you remember?" "When I, friends, was young I used to pass over this banyan keeping it between my thighs, and the topmost shoots brushed against my belly. This, friends, is a long-ago thing that I remember." [And so on until ...] Then, monks, the monkey and the bull-elephant asked the partridge: "You, friend, what longago thing do you remember?" "I, having eaten one of its fruits, relieved myself in that open space, and this banyan has grown from that. So I, friends, am the eldest by birth." Then, monks, the monkey and the bull-elephant spoke thus to the partridge: "You, friend, are the eldest of us by birth. We will respect, revere, reverence, honour you and we will abide by your advice."

Unlike the Four Harmonious Friends folktale and, apparently, Lama Dorji's version, this story is absent one rabbit and is, as one might expect from a book of monastic rules and regulations, principally concerned with promoting respect for one's elders. But the roots of this story don't end in the Buddha's telling of it. Although he is said to have used it to teach his monks deference, there is evidence to suggest, as the Indo-European philologist A. V. Williams Jackson (1918, p. 279) put it, the "Jataka stories, though Buddhistic in form, are really adaptations of still more ancient tales in the land between the Indus and Ganges long before the rise of Buddhism."

11 The section title, "Allowance for the First Seat, etc.," refers to an incident in which younger monks beat their elders to sleeping places inside a house, which elicited a teaching from the Buddha on respect for one's elders. 
Thus, the tale Four Harmonious Friends originally arose from the fecund primordial soup of Indus/Gangetic cultural history. The Buddha then allegedly appropriated and repurposed it to persuade his monks to lead a disciplined life. It was later enshrined in a monastic canon. Later still, Tibetan monks like Lama Dorji promulgated the story as testament to the Buddha's many lifetimes of accumulated merit. Sometime during which all of this was happening, the tale invited a rabbit and artful shoulder stands as laypeople enlivened it in their folklore, where it now models and encourages prosocial behavior in Bhutan.

Where does the "authentic" story begin and where does it end? To paraphrase the Vinaya-Pataka's three friends, what long-ago thing do we remember? Indeed, one might say that this is a tale built of planks from the ship of Theseus. This example of continuity and dependent arising is not exceptional; it epitomizes the nature and culture of heritage. It embodies Liebmann's (2008) complex histories of dynamic adaptation.

\section{Contingent merit versus transformative merit}

In my critique of postcard heritage, I propose that the conventional Western view on heritage focuses on contingent merit, that is, valuations assessed by a market, if you will, of conceptions and perceptions traded by authorities, stakeholder groups, and imagined beneficiaries. The persuasiveness of this construct depends on how tightly we cling to our essentialist notions of heritage and definitions of its meaning and value.

However, from an empty heritage point of view, this approach to merit entirely misses the mark. Alexander Berzin (1999), a noted scholar of Tibetan language and Buddhism, translates the word for merit:

from Sanskrit or Tibetan as "positive potentials" or "positive force," because this is something that arises as a result of acting constructively and which then ripens into happiness ... "Constructive" here means acting in a way that, from the point of view of motivation, is free of attachment ... The fundamental motivation is that it is free of acting out of desire or anger or naivety.

By "free of attachment," Berzin is speaking to the second of the Buddha's "Four Noble Truths," 12 that is, that suffering (one translation of the Pali word, dukkha, which has been alternatively translated as unsatisfactoriness, stress, and, like a wheel, out of true) is caused by clinging to fundamentally impermanent phenomena-material forms, feelings, states of mind, ideas-and resisting their evolution and disintegration. According to this view, transformative potential is latent in all experience and it is possible to access this potential

12 The "Four Noble Truths" refer to the truth of suffering, the truth of the cause of suffering, the truth of the end of suffering, and the truth of the path leading to the end of suffering. 
by relinquishing our grip on these phenomena. This is achieved by cultivating an equanimous and compassionate regard for them and for our attachments to them. Indeed, without equanimity and compassion, it is difficult to be free of acting out of desire (clinging) or anger (from loss) or naivety (about the inexorability of change). In Tibetan Tantric Buddhism, for example, transformative potential is seen in all phenomena, good or bad, profane or sacred. As Powers (1995, p. 226) writes, "in the tantra system, any action - even walking, eating, defecating, or sleeping - can be incorporated into the spiritual path."

This view is embedded in traditional Buddhist custodial practices, which reflect a fundamentally different relationship to heritage than those inspired by the moods and motivations of postcard heritage. For example, Chapagain (2013b, p. 53) writes of Tibetan Buddhists in Nepal:

When the structure is damaged or has deteriorated for any reason, people would rather opt for an entire reconstruction, aiming to give it a better shape, stability, and appearance ... In an archaeologically based conservation ideology, such practices may seem disruptive of the historic patina accumulated on the fabric of the monuments; but these traditions contribute towards the regular upkeep of monuments. ${ }^{13}$

Byrne (2011, p. 5) corroborates this observation from a Southeast Asian vantage point:

In Theravada Buddhism, one of the most meritorious acts involves the restoration of old stupas which have fallen into disrepair or ruin. Rather than following the principles laid down in the 1964 Venice Charter, however, these restorations frequently involve encasing the remains of the original fabric inside a new shell of stucco or brick and stucco ... Stupas which are particularly old have often undergone numerous restorations of this kind and carry inside them the history of what has been done to them in stratified form ... These local practices of restoration can obviously create tension between local pious Buddhists on the one hand and archaeologists, art historians and heritage practitioners on the other ... local people tend to see the sacredness of such structures not as something historical but as a dynamic, living force that is situated solidly in the present [emphasis added].

Thus, with respect to heritage, a concentration on transformative merit includes three key attributes: (1) it inspires an equanimous and compassionate regard for heritage in the context of its impermanence rather than imagined fixity, which (2) fosters regenerative approaches to heritage conservation that (3) appreciate heritage as an interdependent and, therefore, reciprocally evolving process.

13 In the original document, the last sentence in this quotation directly precedes those above it. I invert the order here to improve the flow; the author's intended meaning remains intact. 


\section{Natural heritage: The postcard versus empty red wolf}

My decision to create a new section for this essay with the heading "Natural heritage" reinforces a false dichotomy between culture and nature. In the words of environmental historian William Cronon (1996, pp. 69-70), "As we gaze into the mirror [wilderness] holds up for us, we too easily imagine that what we behold is Nature when in fact we see the reflection of our own unexamined longings and desires." ${ }^{\prime 14}$ To be sure, unexamined longings and desires are the colored sands with which we build a heritage paradigm founded on nostalgianostalgia for an imagined time and place where life was simpler, more authentic, and the natural world was uncontaminated by modernity and its commensals.

One such commensal, Canis latrans, the coyote, traverses the arbitrary and shifting boundaries between wilderness and civilization, nature and culture (Bright, 1987; Sandlos, 1998). Like the wolf (see Zackary 2013), whose role in Euro-American affairs has inspired fear and awe, the coyote has also conjured disgust, frustration, and prejudice. As Sandlos (p. 47) writes, "predatory animals like the coyote have been vilified as bloodthirsty beggars and thieves in the human imagination, a form of conceptual pollution [emphasis added] that must be removed at all cost from the productive landscape."

And yet Canis latrans thrives. Moreover, coyotes continue to threaten to contaminate some of our most pristine constructs of natural heritage. A case in point is the red wolf, Canis rufus (Figure 5). The story more or less goes like this:

The red wolf "once roamed an extensive range including the southeastern United States, and possibly the entire woodlands of eastern North America" (Stoskopf et al., 2005, p. 1146). Due to anthropogenic factors (hunting, habitat destruction, economic development, etc.) and consequent red wolf population decline, the species was listed as endangered in 1967 and extinct in the wild in 1980. Because of fears that pure red wolves would become genetically swamped by a growing hybrid swarm of coyote/red wolves, a small group was discovered and live-trapped in Texas in the mid-1970s and moved to a facility at Point Defiance Zoo in Tacoma, Washington, where their genome was further purified through a captive breeding program. As a result of this effort, wild populations of pure red wolves have been restored in the United States using Point Defiance wolves relocated to eastern North Carolina.

14 I was reminded of Cronon's provocative work while reading an insightful consideration of it in Manganiello's (2009) analysis of the history of red wolf conservation biology. 


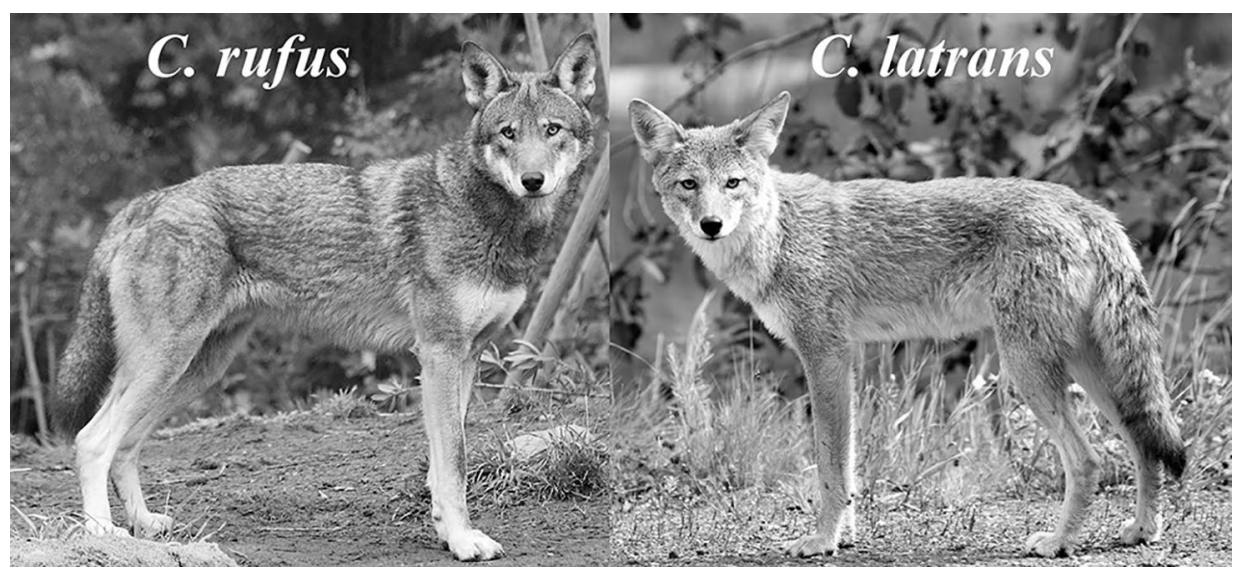

Figure 5. Comparison of red wolf (Canis rufus) and coyote (Canis latrans)

Source: Wikimedia Commons, commons.wikimedia.org/wiki/File:Canis_rufus_\%26_Canis_latrans.jpg. This image is licensed under the Creative Commons Attribution 2.0 Generic license.

This version of the red wolf story is based on others told elsewhere (e.g., Adams et al., 2003; Bohling \& Waits, 201 1; Manganiello, 2009; Roth et al., 2008; Stoskopf et al., 2005) and I intentionally include specific terms repeatedly occurring in those accounts, such as threaten, fear, genetically swamped, hybrid swarm, pure. Let us focus on the words "pure" and "threat" as an example. Using NVivo software, I conducted a textual analysis of 29 peer-reviewed scientific journal articles published between 1992 and 2015 that I collected using the search terms "hybridization" and "Canis rufus" in Web of Science Biological Abstracts and JSTOR Life Sciences Archive Collection online literature databases. Across this sample, the word "pure" occurred 37 times and "threat" occurred 31 times in association with discussion of the red wolf genome, hybridization, and conservation.

But is there really such a thing as a genetically pure red wolf? And is hybridization a mortal threat to this species? One recent study (vonHoldt et al., 2011) assayed over 48,000 single nucleotide polymorphisms (SNPs) from 208 gray wolves (C. lupus), 12 red wolves (C. rufus) and 57 coyotes (C. latrans) to explore their evolutionary heritage. According to the authors' knowledge, this represented at that time "the most extensive SNP survey of any wild vertebrate group" (ibid., p. 1). Results of the study, which reveal the red wolf to be an evolutionary admixture of coyote and gray wolf (e.g., one individual's ancestry was $75 \%$ C. latrans and $25 \%$ C. lupus $),{ }^{15}$ led the authors to seriously question the rationale of a recovery program focused on protecting the introduced wolves from hybridization.

15 The average for the whole sample $(n=12)$ was $76.1 \%$ coyote (C. latrans) and $23.9 \%$ gray wolf $(C$. lupus), with ranges of $74.3-78.1 \%$ and $21.9-25.7 \%$, respectively. 
Add to this a shift in perspectives within the biological sciences community itself. As evolutionary biologist James Mallet (2005, p. 229) writes:

In the course of the development of the biological species concept, a sort of repugnance against hybridization prevailed, akin to the fear on which "Invasion of the Body Snatchers" plays. Supporters of the biological species concept viewed hybridization as a "breakdown of isolating mechanisms." ... These almost eugenic views [emphasis added] about species were particularly prevalent among zoologists because of Ernst Mayr's influence. (By contrast, many botanists thought that introgression ${ }^{16}$ was common and important in adaptive evolution.) The same views led directly to the notorious hybrid policy of the US Endangered Species Act of 1973, by which "hybrids" were deemed unworthy of conservation, whereas unsullied "pure species" were apportioned higher status. But today, tastes in biodiversity are changing, and the biological species concept is under attack.

Indeed, biologist Rodrigo Vargas Pêgas (2013, p. 4) seems to pick up where Mallet leaves off with respect to this argument:

Hybridization between Canis rufus and Canis latrans is seen as negative based on the argument that it might be anthropogenically magnified or that it may threat [sic] the red wolf integrity. If a Homo sapiens who might be up to $4 \%$ Homo neanderthalensis is not considered worthy of sterilization or elimination, then why should a Canis rufus $\times$ Canis latrans hybrid ... be considered so?

Thus, the concept of pure species and, in particular, the species " $C$. rufus" itself seems to dissolve under empirical scrutiny. The red wolf is empty. So, what are we trying so hard to conserve and why? The struggle and concomitant suffering - for example, the failure of a Great Smoky Mountains red wolf colonization project (in part because the wolves preferred a different habitat and voted with their feet) (Manganiello, 2009); conflicts between wildlife professionals and local landowners (Manganiello, 2009); concerted sterilization and killing of coyote and hybrid adults and pups $^{17}$ (USFWS, 2013) - is not caused by hybrid swarms, invasions, and introgression. It is caused by a fear of loss (see Holtorf, 2015). But not loss of something that actually exists. The red wolf that actually exists is a biocultural construct, arising interdependently with its causes and conditions and evolving through reciprocal relations with other organisms, including Homo sapiens, and their environments.

16 Mallet (2005, p. 230) defines introgression as "invasion of foreign genetic material into a genome."

17 "i. If non-wolf females or female associates of non-wolf males localize movement, efforts should be made to determine whether she has a litter, and, if so, it should be removed. ii. If red wolf females localize movements, try to locate the den beginning one week after the suspected whelping date. Blood samples should be taken from each pup for genetic analysis, and transponders inserted. Litters identified as non-wolf following genetic analysis should be removed" (USFWS, 2013, p. 9). 
In sum, when we try to save the postcard red wolf because of its contingent merit for a people, for a people's "nebulous future generations" (Smith, 2006, p. 29), for science, for ourselves, we believe that we are restoring to authenticity an essential aspect of natural heritage. Yet this is like trying to hold onto flowing water. Indeed, in the effort to capture, authorize, and iconize an arbitrary snapshot of the red wolf continuum, a mission motivated by fear of losing another "magic moment" (Mehrotra, 2004, p. 26), we simply produce another postcard of a replica built of planks from the ship of Theseus - one that reflects, like the postcard Indian, our "unexamined longings and desires" (Cronon, 1996, p. 70) rather than the living and evolving beings themselves.

\section{Our heritage is already broken}

In 1981, the venerable Thai Forest Tradition monk Ajahn Chah (2007) gave a teaching during Vassa, or the "Rains Retreat," at Wat Tham Saeng Phet, a Buddhist temple near the town of Amnat Cheroen in eastern Thailand. A portion of this teaching reads:

You say, "Don't break my glass!" Can you prevent something that's breakable from breaking? If it doesn't break now it will break later on. If you don't break it, someone else will. If someone else doesn't break it, one of the chickens will! The Buddha says to accept this. He penetrated the truth of these things, seeing that this glass is already broken. Whenever you use this glass you should reflect that it's already broken. Do you understand this? The Buddha's understanding was like this. He saw the broken glass within the unbroken one. Whenever its time is up it will break. Develop this kind of understanding. Use the glass, look after it, until when, one day, it slips out of your hand ... "Smash!" ... no problem. Why is there no problem? Because you saw its brokenness before it broke!

But usually people say, "I love this glass so much, may it never break." Later on the dog breaks it ... "I'll kill that damn dog!" You hate the dog for breaking your glass ... Why is this? Because you've dammed yourself up, the water can't flow. You've made a dam without a spillway. The only thing the dam can do is burst, right? When you make a dam you must make a spillway also. When the water rises up too high, the water can flow off safely. When it's full to the brim you open your spillway. You have to have a safety valve like this. Impermanence is the safety valve of the Noble Ones. If you have this "safety valve" you will be at peace.

Ajahn Chah's metaphors of the water, dam, and spillway speak directly to the dilemma of heritage conservation in the face of interdependence and impermanence. Let us briefly return to the example of the red wolf. 
From a postcard heritage perspective, we see a species threatened by introgression of coyote genes. We understand how this might happen-habitat degradation, for example, can put a lot of stress on pure wolf populations and, at the same time, encourage incursions by disturbance specialists like coyotes (Bozarth et al., 2011). Species in the genus Canis can interbreed when conditions favor their intermixing, so it should be no surprise that territorial overlap between foreign coyotes and native wolves would lead to "mongrelization"18 (Levin, 2002, p. 255). Thus, what we have here is a flow problem. To fix this problem, we need to prevent the mixing of pure and contaminated water (genes) by building dams (barriers to gene flow). Unfortunately, whenever we install a dam, we discover that the problem is also happening further upstream, so then we need to build another dam. And so on. It also seems that our dams can only hold back the pure water for so long; they inevitably breach our constructs and get contaminated somewhere else downstream. Or it turns out what we thought was pure water has always been contaminated. These efforts and discoveries lead to a never-ending cycle of struggle. What to do?

From a postcard heritage perspective, we see two possible directions. One, of course, is nihilistic and asks, if, despite our best efforts, not all contaminated water can be remediated and the pure water keeps finding ways to contaminate itself, why bother? Remove all the dams and let the water become polluted and the reservoirs run dry. A second direction is frantic and asks, what is there left to do but keep building and reinforcing more and more dams?

These two directions arise from moods and motivations tied to despair and fear of loss and share common essentialist assumptions about the nature of water and dams. Through an empty heritage perspective, however, these assumptions dissolve. Dams cannot function without proper spillways. Water flows downhill and tends to intermix and materialize in many forms. Thus, between nihilistic and frantic directions a middle course, so to speak, emerges - one that is instead pragmatic and asks, where dams are needed, how can their construction be motivated by an understanding of and appreciation for the nature of water? In other words, in the spirit of Russell's (2012, p. 260) quotation at the outset of this essay, how can we learn to love water for what it is rather than what we wish it to be?

Some cultural heritage scholars have addressed this question by exploring, in their own way, the transformative potential of heritage impermanence and destruction (e.g., Fibiger, 2015; Holtorf, 2006, 2015; Karlström, 2009; Peleggi, 2012; Russell, 2012). For example, in his essay on loss aversion and cultural

18 Interestingly, the etymology of mongrel reveals its roots in the words "mong," meaning mixture or mingling and "-rel," a pejorative suffix. From the 1540s, this word was used to denote a "person not of pure race" (Harper, 2015). 
heritage, Cornelius Holtorf (2015) explores the work of Chinese artist and activist, Ai Weiwei, who, in his provocative Dropping the Urn project (Newland, 2010, cited in Holtorf, 2015, p. 413), appears to destroy ancient ceramic vessels by, for instance, submerging them in buckets of paint, painting commercial logos on them, or grinding them into powder. Holtorf argues convincingly that, in Ai Weiwei's apparently iconoclastic act of destroying heritage, he is paradoxically rebirthing it into a new place in the interdependent continuum of Chinese cultural heritage - one that highlights "the loss of historic material culture due to China's rapid modernization and the effects of a globalized economy of mass production on traditional craft work" $(2015$, p. 413). In other words, to extend another of Ajahn Chah's metaphors, when the glass is broken, its shards are seeds for transformation and the creation of new heritage.

In this reading of Chah's teaching, "the glass is already broken" means that the glass (or manuscript, or red wolf, or landscape, or story), even during the time when it is apparently whole, possesses the transformative potential we later observe arising, phoenix-like, from the dissolution of its current form. To see the broken glass in the unbroken one, then, calls for an approach that includes (1) care for the phenomenon as it is now while (2) recognizing its impermanence and nurturing the transformative potential that lies behind the façade of its evanescent form. To do otherwise denies its capacity and proclivity for change and transformative potential and causes unnecessary suffering for it (if it happens to be alive) and for those who care about and for it.

Therefore, moving from a postcard heritage to an empty heritage view entails a paradigm shift, one that not only brings a different perspective on heritage and heritage conservation, but also demands fresh approaches comprising both equanimity and compassion. In this light, Poulios (2015), drawing inspiration from value innovation trends in business management (e.g., Kim \& Mauborgne, 2005), cites the need for a "Blue Ocean Strategy" in cultural heritage conservation, that is, one that challenges existing mental models and redefines the scope and process of conservation itself. As a central part of this strategy, Poulios (2010, 2014, 2015; see also Kimball et al., 2013) calls for an emphasis on living heritage, which requires switching the focus away from conservation of tangible and intangible cultural heritage and toward the communities for which participation in that heritage - and its reciprocally evolutionary processestraditionally sustains and enlivens.

For heritage writ large - the construct that encompasses both cultural and natural phenomena - a Blue Ocean Strategy would support an emphasis on the transformative merit of heritage through a regenerative conservation which fosters efforts that prioritize reciprocal evolution of living heritage over the production and preservation of static replicas. For Mustang Valley's cultural heritage, this might mean reframing conservation research, policy, and practice to include the 
needs, assets, and world views of local placekeepers, rather than an imperative for heritage objects to be "rescued." For the red wolf, it might mean research, policy, and practice that focus on habitat health and wellness and nurture, monitor, and honor the evolution and survival within these habitats of (among other organisms) wild canids, regardless of their color, shape, or resemblances. Photography is welcome, but postcards are not for sale here!

I conclude this essay where I began it - with the story of Bamiyan's Buddhas. This time, however, I re-envision the story based on the work of Bedunah et al. (2010), Blänsdorf \& Petzet (2009), Flood (2002), and Husseini (2012), and insights from an empty heritage perspective. Indeed, this might be a first step in the empty heritage paradigm's pragmatic direction - to revisit the stories we weave and transmit and, then, rewrite them to enable us to see opportunities for regenerative conservation. A re-envisioned Bamiyan Buddhas story might commence like this:

In the mountains of central Afghanistan lies the Bamiyan Valley, a landscape in progress, continuously reworked by seismic activity and the forces of temperature, wind, and water. Likewise, the valley's plant and animal species and communities have morphed, ebbing and flowing over the millennia in sync with grand and local oscillations of warm and cold, wet and dry. These communities and species included various humans and other hominin species as well, whose shifting patterns of migration, subsistence, and social interaction have left their own impressions. Indeed, the roots of the Shia Muslim Hazara extend deeply into the region's aboriginal past and mingle with its complex histories of dynamic adaptation, admixture, conquest, and colonialism. They experienced the arrival of the Silk Road and Buddhism in the 3rd century BCE; the advent of Islam between the 7th and 8th centuries CE; raids, looting, conquest, and iconoclastic destruction between the 5th and 17 th centuries; ${ }^{19}$ Hazara murder and subjugation in the $1890 \mathrm{~s}^{20}$ and by the Taliban at the turn of the 21 st century. Some Hazara believe their people's ancestors carved into a cliff face and decorated with precious ornaments ${ }^{21}$ two colossal Buddha statues about 1,400 years ago. ${ }^{22}$ Through the centuries,

19 For example, the 5th- or early 6th-century CE Hephtalite ruler, Mihirikula, and the 9th-century Saffarid ruler, Yakub ibn Layth (Flood, 2002); the 17th-century Moghul Emperor, Aurangzeb Alamgir, and the Persian Emperor Nadir Shah (Blänsdorf \& Petzet, 2009).

20 'Abdur Rahman, 'the Iron Amir,' invaded and conquered the Hazarajat with Ghilzai tribal (Pashtun) support, reduced thousands of the former inhabitants to slavery, and settled the Ghilzai on much of the land" (Bedunah et al., 2010, p. 42).

21 According to an account by traveling Chinese monk, Xuanzang, who wrote about his visit to Bamiyan in approximately 630 CE (Blänsdorf \& Petzet, 2009).

22 "The present generation of Hazaras believed that the statues were carved by their ancestors with Hazara facial features in antiquity. They therefore believe that these statues are the emblems of their identity" (Husseini, 2012, p. 26). 
in the midst of conquest, subjugation, and outsiders' acts of desecration, ${ }^{23}$ Hazara have done their best to care for Bamiyan's temples, sacred caves, and objects by integrating them into the DNA of their traditions. For example, they wove Bamiyan's Buddhas into a folktale of love, duty, and responsibility in which the warrior hero Salsal completes an odyssey and slays a dragon for his beloved, Princess Shahmama, but the two tragically turn to stone on the eve of their wedding. ${ }^{24}$ Although the Taliban succeeded in destroying much of the tangible remains of the statues, they could not extinguish their transformative merit still alive within the heritage of Hazara placekeepers, some of whom continue to share their stories, others of whom incorporate them into art and poetry of memorialization and resistance $\ldots{ }^{25}$

\section{References}

Adams, J. R., Kelly, B. T., \& Waits, L. P. (2003). Using faecal DNA sampling and GIS to monitor hybridization between red wolves (Canis rufus) and coyotes (Canis latrans). Molecular Ecology, 12, 2175-2186.

Baudrillard, J. (1994). Simulacra and simulation (S. F. Glaser, Trans.). Ann Arbor: University of Michigan Press.

Bedunah, D. J., Shank, C. C., \& Alavi, M. A. (2010). Rangelands of Band-eAmir National Park and Ajar Provisional Wildlife Reserve, Afghanistan. Rangelands, 32(5), 41-52.

Berzin, A. (1999). The Buddhist concept of merit: Does happiness need to be earned? Retrieved from www.berzinarchives.com/web/en/archives/ sutra/level2_lamrim/initial_scope/karma/buddhist_concept_of_merit. html?query=merit.

23 The faces of the Bamiyan Buddhas likely were erased in antiquity, as even 19th-century drawings show their absence (Blänsdorf \& Petzet, 2009). Art historian Finbarr Barry Flood points out that iconoclastic defacement in Islamic history is well documented and suggests that the removal of the Bamiyan Buddha's faces might have been executed under the orders of Yakub ibn Layth in the 9th century (Flood, 2002). Although Blänsdorf and Petzet (2009, p. 18) claim that "there is no evidence for the faces having been destroyed," they footnote this statement with citations to the contrary. Husseini (2012) argues that an alternative explanationthat the faces were fitted with wooden or metallic masks - has no precedent in Ghandaran art.

24 "The people screamed on seeing [that they had turned to stone] and thereafter they lighted candles in those niches and recited tragic poems in their memory. They called it the 'niches of Love' and told this story to the travelers and also named their children after the lovers" (Husseini, 2012, p. 24).

25 For example, Husseini (2012) analyzes and presents examples of contemporary paintings and also writes, "Hazara poets have composed many poems after the destruction. Mourning, and links with Hazara identity and wish for its restoration are common themes" (p. 28). Further, he quotes Hazara artist Khadim Ali: "To me Buddha is my past, my identity. When someone is standing to remove 'my identity,' I must also stand to recreate it" (p. 27). 
Blänsdorf, C., \& Petzet, M. (2009). The giant Buddha statues in Bamiyan: Description, history and state of conservation before the destruction in 2001. In M. Petzet (Ed.), The giant buddhas of Bamiyan: Safeguarding the remains (pp. 17-35). Berlin: ICOMOS.

Bohling, J. H., \& Waits, L. P. (2011). Assessing the prevalence of hybridization between sympatric Canis species surrounding the red wolf (Canis rufus) recovery area in North Carolina. Molecular Ecology, 20, 2142-2156.

Bozarth, C. A., Hailer, F., Rockwood, L. L., Edwards, C. W., \& Maldonado, J. E. (2011). Coyote colonization of northern Virginia and admixture with Great Lakes wolves. Journal of Mammalogy, 92(5), 1070-1080.

Bright, W. (1987). The natural history of Old Man Coyote. In B. Swann \& A. Krupat (Eds.), Recovering the word: Essays on Native American literature (pp. 339-387). Oakland: University of California Press.

Byrne, D. (2011). Thinking about popular religion and heritage. In J. N. Miksic, G. Y. Goh, \& S. O'Connor (Eds.), Rethinking cultural resource management in Southeast Asia: Preservation, development and neglect (pp. 3-14). London: Anthem Press.

Calvino, I. (1974). Invisible cities. London: Harcourt Brace \& Co.

Chah, A. (2007). Still, flowing water. Retrieved from www.ajahnchah.org/book/ Still_Flowing_Waterl.php.

Chapagain, N. K. (2013a). Continuing traditions, decaying material form: Challenging the material authenticity in religious sites in Nepal. Paper presented at the Seventh World Archaeological Congress, Dead Sea, Jordan, January 13-18.

Chapagain, N. K. (2013b). Heritage conservation in the Buddhist context. In K. D. Silva \& N. K. Chapagain (Eds.), Asian heritage management: Contexts, concerns, and prospects (pp. 49-64). New York: Routledge.

Chapagain, N. K. (in press). Perception and management of heritage in the Buddhist context: Observations from Nepal. Proceedings of ICCROM-CHA annual conservation forum on Asian heritage: 1st edition (2013). International Centre for the Study of the Preservation and Restoration of Cultural Property.

Cronon, W. (1996). The trouble with wilderness; or, getting back to the wrong nature. In W. Cronon (Ed.), Uncommon ground: Rethinking the human place in nature (pp. 69-90). New York: W. W. Norton \& Co. 
Evans, S. (2009). The impact of cultural folklore on national values: A preliminary study with a focus on Bhutan. Journal of Bhutan Studies, 20, 3-20.

Fibiger, T. (2015). Heritage erasure and heritage transformation: How heritage is created by destruction in Bahrain. International Journal of Heritage Studies, 21(4), 390-404.

Flood, F. B. (2002). Between cult and culture: Bamiyan, iconoclasm, and the museum. Art Bulletin, 84(4), 641-659.

FPMT (Foundation for the Preservation of the Mahayana Tradition). (2008). The heart of the perfection of wisdom sutra. Portland: FPMT. Retrieved from cdn.fpmt.org/wp-content/uploads/sutras/heart_sutra_bklt_lttr.pdf?3bc25c.

Francis, H. T., \& Thomas, E. J. (1916). Jataka tales. Cambridge: Cambridge University Press. Retrieved from archive.org/details/jatakatales00fran.

Geertz, C. (1973). Religion as a cultural system. In C. Geertz, The interpretation of cultures: Selected essays (pp. 87-125). New York: Basic Books.

Harper, D. (2015). Online etymology dictionary. Retrieved from www.etymonline. com/index.php.

Holtorf, C. (2006). Can less be more? Heritage in the age of terrorism. Public Archaeology, 5, 100-109.

Holtorf, C. (2015). Averting loss aversion in cultural heritage. International Journal of Heritage Studies, 21(4), 405-421.

Horner, I. B. (Trans.). (2014). The book of the discipline: Vinayapitakam. SuttaCentral. Retrieved from suttacentral.net/files/Book_of_the_Discipline.pdf.

Husseini, S. R. (2012). Destruction of Bamiyan Buddhas: Taliban iconoclasm and Hazara response. Himalayan and Central Asian Studies, 16(2), 15-50.

Jackson, A. V. W. (1918). Review of the book, Jataka Tales. The Journal of American Folklore, 31(120), 279-280.

Jokilehto, J. (2006). Considerations on authenticity and integrity in World Heritage context. City \& Time, 2(1), 1-16.

Karlström, A. (2009). Preserving impermanence: The creation of heritage in Vientiane, Laos. Studies in Global Archaeology 13. Uppsala: Uppsala University.

Khisty, C. J. (2006). Meditations on systems thinking, spiritual systems and deep ecology. Systemic Practice and Action Research, 19, 295-307. 
Kim, W. C., \& Mauborgne, R. (2005). Blue ocean strategy: How to create uncontested market space and make competition irrelevant. Cambridge: Harvard Business Review Press.

Kimball, M., Brunswig, R., McBeth, S., \& Thomas, D. (2013). Fostering local futures: Place building theory and the living heritage paradigm. Applied Anthropologist, 33(2), 4-15.

Levin, D. A. (2002). Hybridization and extinction: In protecting rare species, conservationists should consider the dangers of interbreeding, which compound the more well-known threats to wildlife. American Scientist, 90(3), 254-261.

Liebmann, M. (2008). Postcolonial cultural affiliation: Essentialism, hybridity and NAGPRA. In M. Liebmann \& U. Z. Rizvi (Eds.), Archaeology and the postcolonial critique (pp. 73-90). New York: Altamira Press.

Mallet, J. (2005). Hybridization as an invasion of the genome. Trends in Ecology and Evolution, 20(5), 229-237.

Manganiello, C. J. (2009). From a howling wilderness to howling safaris: Science, policy and red wolves in the American south. Journal of the History of Biology, 42(2), 325-359.

Manhart, C. (2009). UNESCO's activities for the saving of Bamiyan. In M. Petzet (Ed.), The giant buddhas of Bamiyan: Safeguarding the remains (pp. 38-40). Berlin: ICOMOS.

Mehrotra, R. (2004). Constructing cultural significance: Looking at Bombay's historic fort area. Future Anterior, 1(2), 24-31.

Newland, J. N. (2010). Ai Weiwei: Dropping the urn. Glenside: Arcadia University Art Gallery.

Noonan, M. (n.d.). "Four friends." Canisius ambassadors for conservation. Canisius College Institute for the Study of Human-Animal Relationships. Retrieved from www.conservenature.org/learn_about_wildlife/biodiversity_in_bhutan/ four_friends.htm.

Pêgas, R. V. (2013). A review on animal hybridization's role in evolution and conservation: Canis rufus (Audubon and Bachman) 1851-A case study. ISRN Zoology. doi: 10.1155/2013/760349. 
Peleggi, M. (2012). The unbearable impermanence of things: Reflections on Buddhism, cultural memory and heritage conservation. In P. Daly \& T. Winter (Eds.), Routledge handbook of heritage in Asia (pp. 55-68). New York: Routledge.

Poulios, I. (2010). Moving beyond a values-based approach to heritage conservation. Conservation and Management of Archaeological Sites, 12(2), $170-185$.

Poulios, I. (2014). The past in the present: A living heritage approach-Meteora, Greece. London: Ubiquity Press. Retrieved from dx.doi.org/10.5334/bak

Poulios, I. (2015). Gazing at the "Blue Ocean" and tapping into the mental models of conservation: Reflections on the Nara+20 document. Heritage \& Society, 8(2), 158-177.

Powers, J. (1995). Introduction to Tibetan Buddhism. Ithaca: Snow Lion Publications.

Reid, L. A. (1993). Another look at the language of the Tasaday. Keynote lecture presented at the Third Annual Conference of the Southeast Asian Linguistic Society (SEALS III), Honolulu, Hawai'i, May 10-17. Retrieved from www. aa.tufs.ac.jp/ reid/Tasaday/Papers/pdffiles/tasl.pdf.

Roth, J. D., Murray, D. L., \& Steury, T. D. (2008). Spatial dynamics of sympatric canids: Modeling the impact of coyotes on red wolf recovery. Ecological Modelling, 214, 391-403.

Russell, I. (2012). Towards an ethics of oblivion and forgetting: The parallax view. Heritage and Society, 5(2), 249-272.

Sandlos, J. (1998). Savage fields: Ideology and the war on the North American coyote. Capitalism Nature Socialism, 9(2), 41-51.

Smith, L. (2006). Uses of heritage. New York: Routledge.

Stoskopf, M. K., Beck, K., Fazio, B. B., Fuller, T. K., Gese, E. M., Kelly, B. T., ... Waits, L. (2005). From the field: Implementing recovery of the red wolfintegrating research scientists and managers. Wildlife Society Bulletin, 33(3), $1145-1152$.

Sullivan, S. (2004). Local involvement and traditional practices in the World Heritage system. World Heritage Papers, 13, 49-55.

UNESCO (United Nations Educational, Scientific and Cultural Organization). (n.d.). Cultural landscape and archaeological remains of the Bamiyan Valley. Retrieved from whc.unesco.org/en/list/208. 
USFWS (United States Fish \& Wildlife Service). (2013). Red wolf adaptive management plan FY13-FY15. Retrieved from www.fws.gov/redwolf/ Images/20130211_RWAMP_2013-2015.pdf.

vonHoldt, B. M., Pollinger, J. P., Earl, D. A., Knowles, J. C., Boyko, A. R., Parker, H., ... Wayne, R. K. (2011). A genome-wide perspective on the evolutionary history of enigmatic wolf-like canids. Genome Research, 21(8), 1294-1305.

Zackary, B. A. (2013). Wolves at the door: Contested space in the American west (Master's thesis, University of Colorado). Retrieved from archive.org/details/ wolves_american_west. 
This text is taken from Human Ecology Review, Volume 22, Number 2, 2016, published 2016 by ANU Press, The Australian National University, Canberra, Australia. 